University of Chicago Law School

Chicago Unbound

Journal Articles

Faculty Scholarship

1937

\title{
Les Conflits de Lois en Matière D'Obligations Contractuelles, selon la Jurisprudence et la Doctrine aux Etats-Unis
}

Max Rheinstein

Follow this and additional works at: https://chicagounbound.uchicago.edu/journal_articles

Part of the Law Commons

\section{Recommended Citation}

Max Rheinstein, "Les Conflits de Lois en Matière D'Obligations Contractuelles, selon la Jurisprudence et la Doctrine aux Etats-Unis," 37 Columbia Law Review 327 (1937).

This Article is brought to you for free and open access by the Faculty Scholarship at Chicago Unbound. It has been accepted for inclusion in Journal Articles by an authorized administrator of Chicago Unbound. For more information, please contact unbound@law.uchicago.edu. 


\section{BOOK REVIEWS}

LES CONFLITS DE LOIS EN MATIÈRE D'OBLIGATIONS CONTRACTUELLES, SELON LA

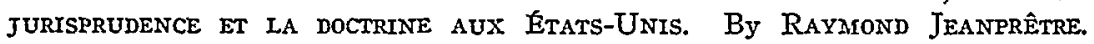
Paris: Librarie Generale de Droit et de Jurisprudence, 1936. pp. 208.

With astonishing unanimity, the courts of the leading European and LatinAmerican countries follow the principle that the validity of a contract is to be determined primarily by the law which the parties themselves have chosen. This principle of the antonomie de la volonté, as it is called in French-speaking countries (Parteiantonomie in German) was widely approved by the school of French and Italian theoreticians who dominated European "Private International Law" in the second half of the 19th century. It was attacked, however, by the following generation of scholars, especially by von Bar in Germany and Pillet in France. Their attacks started with the premise, undeniable within the framework of positivistic legal thought, that an "agreement" between private parties could derive legal force only from some national system of positive law, and that, therefore, the question whether or not a given agreement as to the law applicable to a given contract (a so-called confessio iuris) was valid, could not be answered without knowing first the "proper law" of such agreement. The only alternative to this resort to the proper law of the agreement as controlling the effectiveness of the agreement was to recognize as valid any confessio intris of the parties. But this was said to be an abdication of the sovereign state in favor of private individuals, which would be inconsistent with the very principle of national sovereignty. No longer, so the argument goes, could any state impose upon the individuals the limits within which the legal validity of private agreements was to be determined. By choosing some law accommodating to their wishes, the parties could escape all limits established by the law which "properly" governed the contract. It was thought necessary, however, to give legal force to the wishes of the parties only insofar as "freedom of contract" was recognized by the "proper" law. Thus a distinction between lois obligatoires to be determined "objectively" without reference to the agreement of the parties and the sphere of freedom of contract allowed by the "proper" law to be filled in by the parties, met with the approval of most of the pre-war scholars of Europe. That the scholars exerted some influence upon the courts, was inevitable. It is astonishing, however, that the courts stuck nevertheless to the old intention principle, with the result that a gap was opened between the theorists and the practitioners of the European conflict of laws.

Troubled by such a disquieting state of affairs, Monsieur Jeanprêtre, who is apparently a young Swiss lawyer, went to this country searching for helpful suggestions. The results of his inquiry are set forth in the first part of his book, where he describes the historical development and present state of the American law. Although, superficially, the courts seem to be divided between three apparently inconsistent doctrines, viz. intention of the parties, law of the place of contracting, and law of the place of performance, an analysis of the cases proves to $M$. Jeanprêtre's satisfaction that the latter two rules are merely supplementary to the first one. The overwhelming majority of the cases are said to accept the theory that the parties are free to choose the law by which the validity of their contract should be determined, although the range of choice allowed the parties is rather limited. The parties can choose between two laws only, the lex loci contractus and the lex loci 
executionis. Where the parties have not made such a choice some courts presume that they have chosen the former, others that they have chosen the latter law. To declare, as the Restatement does, the lex loci contractus a hard and fast "rule of attachment," unable to be altered by the parties, is, in M. Jeanprêtre's opinion, not a restatement of the actual American law, but an innovation of questionable expediency.

The second half of M. Jeanprettre's book is mostly devoted to the justification of the intention principle. In accordance with other authors of the present generation, he starts with the propositions that, at least today, the conflict of law rules are national law just as the rules of so-called substantive law, and that each tribunal has to apply the conflict of law rules of its own jurisdiction, i.c. of the lc.x fori. In order to determine which legal system shall furnish the norms for the legal determination of any given social relation, the conflict of laws has to pick out those factual elements which it regards as mostly decisive for establishing a contact between the social relation to be legally determined and some positive legal order. With respect to the legal determination of the social situation called "agreement" or "contract," the lex fori may choose as determining facts the geographical fixation of those utterances of the parties which have given rise to the allegation of the existence of a legally binding contract (lcx loci contractuts), or it may choose the geographical fixation of the acts contemplated to be done in performing the alleged contract (lex loci solutionis), or it may look to the place where one or both of the parties have established the center of their activities of life (lcx domicilii), or it may choose as a determining factor the colors of the flag carried by a ship which has a certain relation to the "making" or to the "performance" of the alleged contract.

There are a good many other facts which may be regarded as having such an essential relation to the alleged relation of the parties that their geographical implications should be taken as the "point of attachment" for the legal determination. Where both parties have uttered sounds or written signs which, in language or writing, extrinsically point at a common intention that a contract the parties are about to make should be governed by the law of a certain jurisdiction, why should any legal system be prevented from using such a fact as "contact," and from declaring that it actually will determine the "validity" of the alleged contract by the law thus referred to by the parties? Such a rule of the conflict of laws does not mean that the parties are placed beyond the "proper law" of the contract, but simply that the lex fori will choose as "proper" law that law which was factually referred to by the parties. That, under the present state of international organization, each lex fori may choose as "proper" law whichever law it wants, can hardly be denied. The only legitimate question at present is whether the choice thus taken is wise and expedient. By demonstrating, as M. Jeanprêtre does, and as the author of this review did a few years ago," that the intention principle is not a logical or "juristic" impossibility, however, the more important question, whether it shall be taken as a contact, is not answered. The observation that the principle is actually applied by the courts almost all over the world is indicative of the existence of some good underlying reason, but it does not show what this reason is. Yet, it can be readily discovered by reflecting upon the raison d'être of the conflict of laws in its entirety. Why do tribunals, now and then, decide controversies according to rules the contents of which have been established not by the law-making authorities of the tribunal's

${ }^{1}$ Review of Hans Lewald, Das deutsche internationalc Privatrccht, (1933) 26 KRITISCHE VIERTELJAHRSSCHRIFT 248, 260. 
own jurisdiction but of some foreign state or nation? They do so largely because parties, when entering upon a certain social relation, e.g. upon matrimony or upon a business transaction, can never know by what state's or nation's tribunals a controversy eventually arising out of their relation will be determined. Yet, the knowledge of how eventual controversies will be decided is frequently a factor essential in determining the parties' resolutions, whether they shall enter upon the relation in question at all, or what they shall try to agree upon in detail. In order to facilitate business and other sorts of social intercourse, the various legal systems existing at present have found it expedient to give would-be contracting parties some possibility of knowing in advance which legal system will furnish the rules by which an eventual controversy will be determined. The law-making authorities have made it known that they will not always apply the substantive law rules elaborated in their own jurisdiction, but that they will sometimes apply the rules of a foreign jurisdiction. If the rules of a foreign jurisdiction are applied, there is a strong argument for applying those rules which were before the parties when they entered upon their transaction. The parties then know where they stand and can direct their resolutions accordingly.

It is queer that such a simple rationale is not conscious to those courts which so consistently adhere to the intention principle. Yet, it not only justifies the principle as wise and expedient, but it also supplies us with the basis for determining the scope and limits of its application.

The problem of the lois abligatoires, which was the actual cause of all the theoretical attacks on the intention principle can be solved only by going back to these essential foundations. In every legal system of our Western Civilization the principle of freedom of contract has found recognition. Everywhere courts (and sheriffs!) will enforce private agreements. Everywhere, the law has announced what must be done before tribunals will recognize the existence of an agreement to be enforced. Everywhere, finally, the law has established a catalogue-sometimes a rather indefinite one-of agreements, the enforcement of which the state will not undertake for one reason or another. These reasons are determined by national policies: The state declares that it will not lend its strong arm to the enforcement of certain promises; society declares that it will not help individuals to enforce agreements whose enforcement would be against the interests of society itself. The state called upon to determine under what circumstances it will set in motion its judges, bailiffs, sheriffs, to enforce an agreement, is that state of which such enforcement is asked. In other words, the law which is interested in determining the so-called limits of freedom of contract is the law of the fortm, even where the "contract" is "governed" by some other law. The limits of freedom of contract, the lois obligatoires are determined by the public policy of the fortun, which may, of course, upon grounds of expediency also deny its help to the enforcement of contracts which, though not in conflict with its own public policy, run counter to the public policy of some other state or country. On proper consideration, however, such situations will rarely occur. If state $X$ has no objections against making contracts on a Sunday, and it is asked to lend its force to the enforcement of a contract made in state $Y$ on a Sunday, what interest has $X$ in denying its help on the ground of state $Y$ 's frowning upon bargaining on Sunday? The only conceivable interest would be a generous feeling of international solidarity and a noble desire to help other countries to enforce their policies. There may be treaties made to such an effect. In their absence, however, the countries of today rarely feel such a desire. They are not particularly eager to help each other enforce their tax or customs laws 
or their laws prohibiting traffic in intoxicating beverages. Why should they be more eager to help enforce foreign Sunday or usury laws, always provided, of course, the enforcement of the agreement in question does not run counter to the public policy of the forum.

Different considerations apply to the determination of the law called upon to state the criteria for the existence of such an agreement as will be legally enforced. The determination of such details as to when a contract is completed (mailing or arrival of the acceptance?) is only slightly affected by considerations of public policies. Though the law of the forum may, in its substantive law rules, state that no contract is complete before the acceptance has reached the offeror, no important public interest is imperilled when, now and then, it lends its power to the enforcement of a transaction in which the acceptance, though properly mailed, has never reached the offeror. If, during their negotiations, both parties were looking to some particular law as being decisive for determining eventual later controversies, then the application of some other law will take them by surprise and lead to disappointment, and there are no reasons why the forum, with respect to these criteria of the "meeting of the minds," should impose upon them some other law.

Such consiclerations as to the raison d'etre of the conflict of laws in general and of the intention principle in particular will also help to determine the sphcre of the latter's application in another respect. If, with M. Jeanprettre, the confessio iuris is regarded not as a contract in the substantive law meaning, but as a mere factual situation, then the question arises of what elements this factual situation is composed. The determination can only be made by the conflict of law rules of the forum. In other words, if the confessio iuris is regarded as an agrcement, the requirements of its validity must be legally determined, though not by the rules of the substantive law of the forum with respect to contracts in general. The conflict of laws of the forum must rather define for itself the elements under which the existence of a valid confessio intris will be recognized. That these requirements will be less stringent than those established by the substantive law of the forum for contracts in general goes without saying. This problem is touched upon though not elaborately dealt with by our author. He could have found searching discussions in two recent German publications which take up this question quite in detail. ${ }^{2}$

It seems, however, that such discussions miss the gist of the problem. If we acknowledge that the legal controverises arising out of a contractual obligation ought to be governed primarily by the law which the parties had in mind, then it follows that this law ought to be applied not only where the parties expressly "agreed" on it, but also. where it was in both of their minds more or less unconsciously. This is exactly what German, French, American and other courts do when, in default of an express confessio intris, they are searching for an "implied" agreement as to the law applicable to the contract. M. Jeanprêtre does not appear to approve of this general practice. Where there is no express confessio itris, he seems to be inclined to determine the law applicable to the contract by other criteria. Once, the underlying policy is understood, however, the intention

${ }^{2}$ Haudek, Die Bedeutung des Parteiwillens iar Internationalen PrivATRECHT (1931); Wahl, Die deutsche Rechtspreching in einzelncu Lehren des internationalen Privatrechts. Das Zustandekommen der Willcuserklaeruingcn (1929) 3 ZEITSCHRIFT FUER AUSLAENDISCHES UND INTERNATIONALES PRTVATRECHT 775. 
principle properly applies to all those transactions in which it can be found that the parties, when entering lipon their transaction, were acting on the basis of some given law, however unexplicit this idea may have been in their minds. To express this idea in the form of an "agreement" of the parties being the basis for the choice of law, is misleading.

There remain those situations where the parties were acting without any thought as to the law which might be applied to solve eventual later difficulties. If such difficulties actually arise, the conflict of laws of the formm has to decide authoritatively which substantive law's rules shall be called upon, and that solution is the best which is the most easy to apply and which most likely leads to international conformity of decision. M. Jeanpretre demonstrates convincingly that, under such a test, the lex loci contractus is a superior supplementary conflicts rule to the lex loci solutionis.

MAX RHeinstein*

Cases and Statutes on Business Associations. By Alexander H. Frey. Chicago: Callaghan and Co., 1935. pp. xxvii, 1331. $\$ 6.50$.

In an admirably analytical and thoroughgoing way, Professor Frey has interspersed approximately 49 pages of expository or textual material ${ }^{2}$ and 73 pages of representative statutes ${ }^{2}$ among 311 principal cases selected from 42 jurisdictions. $^{3}$

* University of Chicago Law School.

${ }^{1}$ Either written by the editor, frequently in the form of pertinent questions designed to direct the student's thought, or else carefully selected from textual or current periodical literature.

${ }^{2}$ Drawn almost exclusively, however, from California and Delaware. The Uniform Partnership and Limited Partnership Acts and the Uniform Stock Transfer Act are printed in full in the Appendix, along with pertinent provisions of the Uniform Fraudulent Conveyance Act and of the Federal Bankruptcy Act as applied to partnerships. Aside from the non-corporate material and the corporation laws of the two states mentioned, the reviewer has noted but three references to the Uniform Business Corporation Act, one to the Ohio Corporation Laws, one to the laws of New York and two of those of Pennsylvania. The editor attaches especial importance to the California Act as the expert work of Professor Ballantine and to the laws of Delaware as the leading incorporating state, and urges each student "to equip himself with a copy of the general incorporation act of the state in which he intends to practice and to regard its provisions as part of the material to be studied." Even so, it is doubtful if there is offered sufficient jurisdictional variation to justify any assumption that one of the unique features of this casebook lies in its extension of the fundamentals of the "case" system to statutory materials. Of course the principal cases are frequently selected to apply directly to statutory problems adequately set forth therein.

${ }^{3}$ No jurisdiction is here given greater prominence than its incorporating or industrial importance justifies. The cases are distributed jurisdictionally as follows: Federal courts-58 (22 from the United States Supreme Court and 36 from the circuit courts of appeal and district courts representing each of the 10 federal circuits but predominantly the 2d); New York-50; Pennsylvania-29; Delaware-19; New Jersey-18; Massachusetts-13; California-12; Illinois and Minnesota-9 each; Virginia -7; Kentucky, Texas, and Wisconsin-6 each; Arkansas-5; Georgia, Iowa, Indiana, Kansas, Ohio, and Oklahoma-4 each; Alabama, Great Britain, Mississippi, Missouri, and North Carolina-3 each; Arizona, Colorado, Connecticut, Florida, Nebraska, Tennessee, Utah, and West Virginia-2 each; and Idaho, Maryland, Michigan, Montana, North Dakota, Oregon, South Carolina, Washington, and Wyoming-1 each. Louisiana, Maine, Nevada, New Hanpshire, New Mexico, Rhode Island, South Dakota, and Vermont are the only jurisdictions within the United States unrepresented. 